\title{
EXERCITUS BARBARORUM. ORGANIZACJA I DZIALANIA WOJSK LUDÓW GERMAŃSKICH OSIADEYCH W V I VI WIEKU W BASENIE MORZA ŚRÓDZIEMNEGO
}

1. Baza źródłowa. Podstawowym problemem jest stan źródeł, które zdaniem niektórych badaczy - nie dają możliwości dokładniejszego wglądu w problematykę organizacji wojsk królestw germańskich V i VI wieku. Choć nie do końca można zgodzić się z tym zdaniem, przyznać jednak trzeba, że źródła pozostające do naszej dyspozycji są specyficzne i w większości jednostronne. Badania nad każdym rodzajem historii barbarzyńskich królestw V i VI w. wymagają analizy nie tylko źródeł dotyczących wydarzeń politycznych, administracyjnych i militarnych ${ }^{1}$, ale także, a może przede wszystkim

* Prof. dr hab. Marek Wilczyński - Kierownik Katedry Historii Starożytnej w Instytucie Historii na Wydziale Humanistycznym Uniwersytetu Pedagogicznego im. Komisji Edukacji Narodowej w Krakowie; e-mail: wilczynski.m@wp.pl.

${ }^{1}$ Dla początku okresu interesujący jest Ammianus Marcellinus, Res gestae libri XXXI (Ammien Marcellin, Histoires, Collection des Universités de France, t. 1-6, Paris 1968-1999, różni edytorzy poszczególnych tomów - w dalszych przypisach w tym artykule w każdym przypadku zostanie podany dokładnie tom i edytor). Oczywiście autor ten żył i tworzył w IV w., jednak jego tekst, zawierający nie tylko relacje kronikarskie, ale także ekskursy etnograficzne i opisy zwyczajów ludów barbarzyńskich, jest niezbędnym wprowadzeniem do badań nad wojskowością germańską V i VI wieku. Wiadomo, że taktyka walki się zmieniała, nie na tyle jednak szybko, by zakładać, że działania jednostek Wizygotów w bitwie pod Adrianopolem odbiegały diametralnie od taktyki stosowanej przez dowódców państwa tuluzańskiego w bitwach pod Arelate czy na polach Paramo. Dla V w. na pewno ważna jest historia Pawła Orozjusza, Historiarum adversum paganos libri VII, a konkretnie jej siódma księga [Orose, Histoires (Contre les Païens), t. 3, texte établi et traduit par M.-P. ArnaudLindet, Paris 1991], zawierająca opisy działań wojennych Rzymian i barbarzyńców w początkach wieku. Także dla samego początku V w. wartościowy jest przekaz Zosimosa (Historia Nova, ed. L. Mendelssohn, Lipsiae 1887). Źródłem ciekawych, choć bardzo nielicznych informacji mogą być zachowane fragmenty dzieł Olimpiodora (Olympiodorus, Historiarum librorum XXII fragmenta, w: The Fragmentary Classicising Historians of the Later Roman Empire. Eunapius, Olympiodorus, Priscus and Malchus, t. 2: Text, Translation and Historiographical Notes, ed. by R.C. Blockley, ARCA Classical and Medieval Texts, Papers and Monographs 10, Liverpool 1983, 151-207). Przekazy kronik łacińskich V w., o których będzie jeszcze mowa poniżej, ze względu na niezwykle lakoniczną formę przekazu i zainteresowanie głownie najważniejszymi wydarzeniami z życia państwa i Kościoła nie dostarczają wielu szczegółów na temat organizacji wojsk barbarzyńskich, 
różnorodnych źródeł proweniencji kościelnej. Wynika to z sytuacji w jakiej znajdowały się terytoria zajmowane przez barbarzyńców. W większości przypadków rzymska administracja centralna traciła nad nimi kontrolę, co połączone było z zaniknięciem cesarskiej struktury wojskowo-administracyjnej. Nie tylko w Rzymie w czerwcu 455 r., ale i w wielu innych miastach Galii, Hiszpanii, Afryki, Brytanii czy Noricum jedyną władzą i jedynym autorytetem zdolnym organizować obronę lub podejmować rokowania z najeźdźcami byli hierarchowie Kościoła ${ }^{2}$. Przy okazji badania relacji o przybyciu barbarzyńców zawartych w lokalnych źródłach proweniencji kościelnej można znaleźć kilka interesujących wzmianek o sposobie działania barbarzyńskich jednostek bojowych. Równocześnie wobec różnic wyznaniowych oddzielających Rzymian od Gotów, Wandalów i Burgundów Kościół katolicki i jego hierarchia prędzej czy później stawali się stroną konfliktu, który w przypadku niektórych państw [afrykańskie królestwo Wandalów, wizygockie królestwo tuluzańskie za panowania Euryka (ok. 420-484; król od 466) i Alaryka II († 507; król od 484)] przybierał formę na tyle ostrą, że dochodziło do używania przez państwo wobec Kościoła katolickiego przemocy, także z zaangażowaniem struktur militarno-policyjnych. Relacje o tych wydarzeniach mimo, że autorom brakowało fachowej wiedzy wojskowej, przynoszą sporo interesujących szczegółów4

kontentując się raczej relacjami o skutkach ich działań. Dopiero w wieku VI pojawiają się znowu materiały umożliwiające gromadzenie szerszych informacji. Przede wszystkim monumentalne dzieło Prokopiusza z Cezarei (De bellis I-VIII, w: Procopius Caesariensis, Opera omnia, vol. 1-2, ed. J. Haury, Lipsiae 1952) podobnie jak historia Ammiana Marcellina bogate w ekskursy informujące o barbarzyńcach i ich obyczajach. Równie interesujący jest kontynuator prac Prokopiusza, Agatias z Myriny (Agathias Myrinaeus, Historiarum libri quinque, ed. R. Keydell, Berolini 1967). Istotnych informacji dotyczących hierarchii tak wojskowej jak i cywilnej w królestwie Ostrogotów w Italii dostarcza nieoceniony zbiór dokumentów kancelarii królewskiej zgromadzony przez Aureliusza Kasjodora (Aurelius Cassiodorus, Variae, ed. Th. Mommsen, MGH Auctores Antiquissimi XII, Berolini 1894, 1-385).

${ }^{2}$ Bardzo dobrym studium na ten temat jest praca Susanne Baumgart (Die Bischofsherrschaft im Gallien des 5. Jahrhunderts. Eine Untersuchung zu den Gründen und Anfängen weltlicher Herrschaft der Kirche, Münchener Arbeiten zu Alten Geschichte 8, München 1995).

${ }^{3}$ Jestem świadom niedoskonałości użytego określenia, w odniesieniu do omawianego okresu jednak jakiegoś użyć trzeba. By nie narazić się na zarzut zaniedbań terminologicznych wyjaśniam, że używając w tym tekście w stosunku do Kościoła określenia „katolicki” mam na myśli Kościół wyznający prawdy wiary zatwierdzone na czterech pierwszych kanonicznych soborach powszechnych. W przypadku królestw Gotów i Wandalów, czyli ludów wyznających herezję ariańską w postaci przekazanej Gotom przez Wulfilę (ok. 310-383) oraz Swebów oscylujących pomiędzy pogaństwem, arianizmem i katolicyzmem, najważniejszym wyznacznikiem była wierność kanonom I Soboru Powszechnego w Nicei (325) i dlatego pisząc o Kościele katolickim mam na myśli przede wszystkim wyznawców dogmatu homouzjańskiego.

${ }^{4}$ Źródeł proweniencji kościelnej, z których korzystać można w badaniach nad wojskowością barbarzyńską, jest sporo. Wymienić należy te najważniejsze - Wiktor z Wity: Victor Vitensis, Historia persecutionis Africanae provinciae tempore Geiserici et Hunerici regum Wandalorum (w tym artykule wykorzystałem stosunkowo nową edycję Konrada Vössinga opatrzoną podtytułem 
Następną grupą źródeł są utwory literackie Klaudiusza Klaudiana (ok. 370 - ok. 405), Flawiusza Merobaudesa (V w.), Nie wolno też zlekceważyć zachowanych pomników prawa ludów germańskich - w omawianym przypadku chodzi o Leges Visigothorum.

\section{Liczebność sił zbrojnych królestw germańskich V i VI wieku.} Zagadnienie wielkości potencjału militarnego, jakim dysponowali władcy barbarzyńców, pozostaje przedmiotem stałych dyskusji naukowych. Na przeszkodzie stoi brak jednoznacznych źródeł pisanych oraz znana wszystkim badaczom antyku swoboda, z jaką autorzy źródeł podchodzili do danych liczbowych. Często podana oszałamiająca liczba kilkudziesięciu, a nawet kilkuset tysięcy może po prostu oznaczać „bardzo wiele”, jednak przy ostrożnym podejściu do źródeł można się pokusić o próbę powierzchownego i na pewno obciążonego błędem szacunku.

W czasie walk prowadzonych przez cesarza Probusa (232-282, cesarz od 276) wzięto do niewoli i wcielono do armii rzymskiej 16 tys. Germanów ${ }^{5}$ Ammianus Marcellinus (ok. 330 - ok. 395) relacjonując działania cesarza Juliana Apostaty (ok. 331 - 26 VI 363; cesarz od 3 XI 361) przeciwko Alemanom, dowodzonym przez Chnodomara (król w latach 352-357) pisze, że sam Chnodomar oraz sprzymierzeni z nim czterej królowie i dziesięciu książąt dysponowali łącznie 35 tys. wojowników ${ }^{6}$, co daje średnią arytmetyczną po ok. 2 tys. wojowników na wodza, choć z całą pewnością poszczególne kontyngen-

Kirchenkampf und Verfolgung unter Vandalen in Africa, Darmstadt 2011, wydanie bilingwiczne z komentarzem), gdzie znajdziemy sporo informacji o sposobach stosowania przymusu i terroru przez Wandalów, ale także o strukturze organizacji królestwa i jego armii. Zaliczane do kronik ogólnych V w., ale silnie związane z historią Kościoła kronikarskie dzieło Hydacjusza (ok. 400 - ok. 470) biskupa Aquae Flaviae (Hydatius Lemicus, Continuatio chronicorum Hieronymianorum ad a. CCCCLXVIII, w: Chronica minora saec. IV. V. VI. VII, vol. 2, ed. Th. Mommsen, MGH Auctores Antiquissimi XI, Berolini 1894, 1-36) informuje o działaniach wojowników swebskich za panowania królów od Hermeryka do Rechimunda. Z kolei w realia późnego kresu istnienia królestwa Swebów w Hiszpanii wprowadzają dzieła Marcina z Bragi (ok. 520 - ok. 580) i dokumenty synodów luceńskiego (Divisio Teudemiri, w: Liber fidei sanctae Bracarensis ecclesiae, t. 1, edição crítica por A. de Jesus da Costa, Braga 1965, 16nn). Chociaż Sydoniusz Apolinary (Sidonius Appolinaris, Epistulae et carmina, ed. Ch. Luetjohann, MGH Auctores Antiquissimi VIII, Berolini 1887, 1-264: Epistulae, s. 1-172; Carmina, s. 173-264) nie przez całe swoje życie należał do stanu duchownego, jednak jego listy, w większości pisane już po 472 r., odzwierciedlają sytuację w zajmowanej przez Wizygotów Owerni, ale też w całej Galii i cesarstwie, a pisane wcześniej pieśni informują także we fragmentach o wojskowości barbarzyńskiej.

${ }^{5}$ Por. Flavius Vopiscus, Probus XV 1nn, ed. w: The Scriptores Historiae Augustae, with an english translation by D. Magie, vol. 3, LCL 263, Cambridge (Massachusets) - London [reprint 1998], 367.

${ }^{6}$ Por. Ammianus Marcellinus, Res gestae lib. XVI 12, 26, ed. É. Galletier: Ammien Marcellin, Histoires, t. 1: Livres XIV-XVI, texte établi et traduit par É. Galletier avec collaboration de J. Fontaine, Paris 1968, 179. 
ty nie były równe i musiały zachodzić różnice w ich liczebności, ale nie mogły to być różnice drastyczne. Ogromne siły Radagaisa († 23 VIII 406) budziły w 405/406 r. przerażenie w Italii i sam wódz musiał je podzielić z powodów trudności aprowizacyjnych, jednak po jego klęsce Stilichon (ok. 360 - 22 VIII 408) wcielił do wojska rzymskiego jeszcze 12 tys. optimates Radagaisa ${ }^{7}$. Z kolei informacje z okresu panowania króla wizygockiego Walii (415-418) dostarczają szansy na dokonanie obliczenia odbiegającego od sztampowego podawania liczby ogólnej wojsk lub jeńców. Z relacji Olimpodora z Teb (V w.) dowiadujemy się, że Walia zdecydował się wydać wodzowi cesarza Honoriusza (9 XII 384 - 15 VIII 423; cesarz od 17 I 395), Konstancjuszowi, późniejszemu Konstancjuszowi III (ok. 370 - 2 IX 421; cesarz od 8 II 421), siostrę Honoriusza, Gallę Placydię (ok. 390 - 27 XI 450) za dostawę żywności w wysokości 600 tys. modii (korców) zboża ${ }^{8}$, co w przeliczeniu daje 6, $3 \mathrm{mln}$. litrów. Jak wynika z relacji dostawa ta miała wystarczyć całemu ludowi na rok. Przyjmując te dane Herwig Wolfram szacuje, że był to zapas pozwalający wykarmić w ciągu roku 15 tys. wojowników z rodzinami ${ }^{9}$. Znany dobrze przekaz Prokopiusza z Cezarei (ok. 500 - ok. 562) dotyczący liczebności Wandalów przynosi wiadomość, że przed inwazją na Afrykę Wandalowie i Alanowie zostali podzieleni przez Gejzeryka (ok. 390 - 15 I 477; król od 428) na 80 jednostek dowodzonych przez tysięczników, choć Prokopiusz jest zdania, że król zawyżył w celach propagandowych liczbę swojego ludu, i że w istocie Wandalów i Alanów było tylko 50 tysięcy ${ }^{10}$. Podobnego zdania w tej kwestii był Wiktor z Wity (ok. 435 - ok. 490), który pisał, że Gejzeryk chciał stworzyć wrażenie, że przewodzi ludowi liczącemu 80 tys., jednak w części byli to starcy i dzieci ${ }^{11}$. Z kolei Malchus (V w.) informuje, że w czasie rokowań z Adamancjuszem (V w.) Teodoryk Amal (ok. 451 - 30 VIII 526; król od 474) wyraził gotowość wsparcia cesarza Zenona (ok. 425 - 9 IV 491; cesarz od 9 II 474) przeciw Teodorykowi Strabo (†481) kontyngentem w sile 6 tys. wojowników, a ogólną liczebność armii Teodoryka Amala szacował na 13 tysięcy ${ }^{12}$. Brak informacji o liczbie wojowników swebskich, którzy najechali Hiszpanię w roku 409, jednak Wilhelm Reinhart, Luis Gonzaga de Azevedo (1867-1930) i Jean Pierre Leguay (29 V 1938 - 27 II 2013) oszacowali maksymalne siły militarne Swebów odpowiednio od 5 tys., przez 8 tys. do 15 tys., maksymalnie ${ }^{13}$.

\footnotetext{
${ }^{7}$ Por. Olympiodorus, Fragmenta 9, ed. Blockley, vol. 2, s. 162. Optimates byli doborową drużyną wodza i ludźmi do specjalnych zadań, a nie zwykłymi wojownikami, co tym bardziej utrudnia próbę określenia liczebności hord Radagaisa.

${ }^{8}$ Por. tamże 30, ed. Blockley, vol. 2, s. 194.

${ }^{9}$ H. Wolfram, Die Goten. Von den Anfängen bis zur Mitte des sechsten Jahrhunderts. Entwurf einer historischen Ethnographie, München - Wien 199033 177.

${ }^{10}$ Por. Procopius Caesariensis, De bellis III 5, 18, ed. Haury, vol. 1, s. 334.

${ }^{11}$ Por. Victor Vitensis, Historia persecutionis I 2, ed. Vössing, s. 34.

${ }^{12}$ Por. Malchus, Fragmenta 18, ed. Blockley, vol. 2, s. 427-428.

${ }^{13}$ Por. W. Reinhart, O Reino Hispânico dos Suevos, Coimbra 1944, 18; tenże, Los Suevos
} 
Oczywiście wielkość armii musiała być w każdym z królestw V i VI w. odmienna, choć nie należy przypuszczać, że różnice były bardzo duże. Wydaje się, iż powinno się ostrożnie przyjąć, że armia plemienna Wandalów i Gotów mogła liczyć kilkanaście tysięcy wojowników. Armia Swebów była chyba mniej liczna, na co wskazuje nie tylko stosunkowo niewielkie terytorium przejęte pod bezpośrednią kontrolę przez króla Hermeryka (ok. 360-441; król a latach 409-438) po zajęciu Rzymskiej Galicji (Galaecia/Callaecia) oraz długotrwałe i poważne kłopoty z lokalną samoobrona, ale też efekty starć militarnych z potężniejszymi sąsiadami, takimi jak Wandalowie czy Wizygoci. Pierwszym Swebowie uszli z blokady w Górach Nerbasyjskich jedynie dzięki interwencji rzymskiej, a drugim nie potrafili ani w V ani w VI w. stawić skutecznego oporu. Wszelkie próby dokładnego oszacowania liczebności armii królestw germańskich powstałych na terytorium zachodniorzymskim obciąża jednak jeszcze jedna niewiadoma. Jest nią liczba przedstawicieli ludności prowincjonalnej służącej militarnie władcom wandalskim, gockim, swebskim, czy burgundzkim. Na pewno Rzymianie byli czynni w wandalskiej flocie, a oddziały Maurów stanowiły uzupełnienie wandalskich jednostek bojowych. W armii Wizygotów spotykamy wysokich rangą dowódców pochodzenia rzymskiego, a do walki przeciw Frankom wzywano także rzymskich poddanych Alaryka II. Proces wciągania ludności prowincjonalnej do służby wojskowej nie przybrał jednak w omawianym okresie takiego rozmiaru jak później w toledańskim królestwie Wizygotów, kiedy to np. za panowania Wamby $(\dagger 688$; król w latach 672-680) zobowiązano możnych i posiadaczy ziemskich do uzbrojenia na potrzeby pospolitego ruszenia co dziesiątego z zależnych od nich poddanych ${ }^{14}$.

3. Organizacja armii. Bardzo ciekawe wyniki badań archeologicznych nad znaleziskami bagiennymi w Illertrup w Danii zostały opublikowane i zinterpretowane przez Michaela Hepera i Haiko Steuera ${ }^{15}$. Badaczy zainteresował inwentarz ofiar błotnych z okresu pomiędzy 200 a 500 r., a szczególnie umba tarcz z których 300 wykonano z żelaza, 40 z brązu, a 5 ze srebra. Wśród tarcz posiadających srebrne umbo jedna była dodatkowo zdobiona kamieniami półszlachetnymi. Autorzy wyciągnęli stąd wniosek, że stosunek tarcz z umbo

en tiempo de su invasion en Hispania, „Archivo Español de Arqueología” 63 (1946) 311 (podaje ustalenia Luisa Gonzagi de Azevedo); J.P. Leguay, O „Portugal” Germânico, w: Nova História de Portugal, vol. 2: Portugal das invasões germânicas à ,, Reconquista”, direcção de J. Serrão e A.H.R. de Oliveira Marques, Lisboa 1993, 27.

${ }^{14} \mathrm{Na}$ temat srogich kar za nie respektowanie zasady powszechnego poboru i obowiązków feudałów w zakresie obronności zob. dalej nota 33.

${ }^{15}$ Por. M. Hoeper - H. Steuer, Zu germanischen „Heeresverbänden” bzw. „Heerlagern” im Spiegel der Archäologie, w: Rom, Germanien und die Ausgrabungen von Kalkriese, Internationales Kongress der Universität Osnarbrück und des Landschaftsverbandes Osnarbrücker Land e. V. vom 2. bis 5., hrsg. von W. Schlüter und R. Wiegels, September 1996, Osnarbrücker Forschungen zu Altertum und Antike-Rezeption 1, Osnarbrück 1999, 467nn. 
zdobionym srebrem do pozostałych może odzwierciedlać stosunek przywódców do prostych wojowników. Otrzymana proporcja 1:60 odpowiada podziałowi na setki, podobnie jak w armii rzymskiej na centurie (rzymska centuria też nie osiagała pełnej liczby 100 legionistów). Podział na jednostki dowodzone przez tysięczników potwierdzony jest źródłowo zarówno u Wandalów, jak i u Wizygotów, a już Felix Dahn (9 II 1834 - 3 I 1912) w wydanej w 1899 r. historii ludów germańskich i romańskich twierdził, wprawdzie bez podania podstawy źródłowej swoich tez, że powoływana w ramach pospolitego ruszenia armia germańskich królów dzieliła się na dziesiątki, setki i tysiące ${ }^{16}$. Źródłowo poświadczone są wszystkie te jednostki (i dodatkowo jeszcze pięćsetka), poprzez wymienienie nazw ich dowódców w aktach prawnych prawa wizygockiego dotyczących zagadnień wojskowych ${ }^{17}$.

Plemienne armie Gotów, Wandalów i Swebów, ewoluujące po stałym osiedleniu się w kierunku organizacji armii poszczególnych królestw, miały na pewno jedną cechę wspólną - skupiały się wokół osoby wodza/króla. W strukturze organizacyjnej społeczności wszystkich wymienionych państw król posiadał wszelką władzę w zakresie administracji cywilnej i militarnej. Był więc głównodowodzącym armii zarówno jako wódz plemienia (w odniesieniu do wolnej i niewolnej ludności germańskiej) oraz jako zwierzchnik ludności rzymskiej $^{18}$. Swoje uprawnienia mógł cedować na członków arystokracji plemien-

${ }^{16}$ Por. F. Dahn, Die Goten, Essen 1990, 434-435. Jest to wznowienie pierwszego tomu czterotomowej wersji pierwotnej Urgeschichte der germanischen und romanischen Völker z $1899 \mathrm{r}$.

${ }^{17}$ Por. Leges Visigothorum IX 2, 1 i 4, ed. K. Zeumer, MGH Leges, sectio I: Leges nationum germanicarum, t. 1: Leges Visigothorum, Hannoverae - Lipsiae 1902, 366 i 368. Cytowane postanowienia dotyczą kar za dezercję w wojsku Wizygotów, dotyczących wszystkich poziomów dowodzenia. Grupując wymienionych w tych dokumentach od rangi najniższej do najwyższej otrzymamy następującą strukturę: decanus, centenarius, quingentenarius i thiufadus (piufaps).

${ }^{18}$ Pamiętać należy, że w toku dwóch wieków formalny status władców germańskich zmieniał się. Początkowo cesarstwo starało się narzucić im status foederati, co wprawdzie dawało pewną władzę nad ludnością rzymską na przyznanych plemieniu pod osiedlenie terytoriach, ale z licznymi wyjątkami i wykluczeniami (np. miast), uszczuplającymi zakres kompetencji królów (więcej na temat pozycji i zakresu władzy królów germańskich w państwach okresu Wędrówki Ludów, por. G. Maier, Amtsträger und Herrscher in der Romania Gothica. Vergleichende Untersuchungen zu den Institutionen der Ostgermanischen Völkerwanderungsreiche, Historia Einzelschriften 181, Stuttgart 2005, 69nn i 262nn; por. też M. Wilczyński, Ile „Romanii” a ile „Gotii” w państwach Gotów, Swebów i Wandalów w Vi VI w. n.e., w: Instytucje „wczesnego państwa” w perspektywie wielości i różnorodności kultur, red. J. Banaszkiewicz - M. Kara - H. Mamzer, Poznań 2013, 207nn. O statusie i politycznym znaczeniu foederati, zob. R. Scharf, Foederati. Von der völkerrechtlichen Kategotie zur byzantinischen Truppenverwaltung, Wien 2001 (dla omawianego tematu szczególnie ważne są rozdziały I-V). Wypadkiem szczególnym było ostrogockie królestwo Amalów w Italii, gdzie mimo rzeczywistej kontroli Teodoryka Wielkiego nad wszelkimi aspektami italskiej polityki, zachowany był jednak formalny podział na władzę królewską nad plemieniem i władzę na mocy posiadanego urzędu rzymskiego w formalnej służbie cesarskiej nad rzymską ludnością Italii, co sprawia, że Italii pod panowaniem Ostrogotów nie można traktować jako królestwa germańskiego, ale raczej jako formę kontynuacji władzy rzymskiej sprawowanej w imieniu cesarza przez króla 
nej, urzędników zarówno barbarzyńskiego, jak i rzymskiego pochodzenia czy nawet na dowódców niższego szczebla, nigdy jednak z nich nie rezygnował, a kampanie wojenne przeprowadzane pod bezpośrednim dowództwem królów nie należały do rzadkości, choć zarówno w dziejach Gotów, jak i Wandalów znane są liczne przypadki przekazywania dowództwa duksom i komesom ${ }^{19}$. Na niższych szczeblach dowodzenia zróżnicowanie w zależności od królestwa było większe, a więc mimo podobieństw pomiędzy organizacją germańskich królestw obszaru Morza Śródziemnego, istniejące też różnice powodują konieczność dalszego omawiania organizacji armii (i floty wojennej) w każdego z tych królestw osobno.

W królestwie Wandalów armia, przynajmniej w głównym jej trzonie, zachowała chyba największą spoistość etniczną w porównaniu $\mathrm{z}$ armiami innych królestw. Nie oznacza to, że we wszystkich rodzajach sił zbrojnych służyli wyłącznie Wandalowie i Alanowie. Jednak elita armii, czyli królewska kawaleria, wydaje się być etnicznie jednolita, co wiązać można z pewnością ze ściśle przestrzeganą w królestwie od czasów Gejzeryka zasadą utrzymywania dystansu między ludnością plemienną a prowincjonalną. Wpływał na to szczególnie ostry w Afryce konflikt religijny pomiędzy nowymi panami diecezji, a ludnością miejscową. Represyjna wobec Kościoła katolickiego i jego rzymskich wyznawców polityka Gejzeryka, Huneryka (ok. 420-484; król od 477) i Thrasamunda (ok. 450-523; król od 496) utrudniała integrację, którą w innych królestwach można z czasem obserwować. Inną przyczyną było założone z góry, a zrealizowane po zajęciu Kartaginy jesienią 439 r., stworzenie zwartego zaplecza wojskowego wokół stolicy. Gejzeryk wyraźnie nie życzył sobie zmieszania swego ludu z mieszkańcami prowincji, tworząc wokół swojej stolicy tereny zwartego osadnictwa wojowników, czyli tzw. sortes Vandalorum ${ }^{20}$. Posunięcie to stworzyło sprowadzoną do konkretne-

Ostrogotów na ustalonych ściśle warunkach, por. J. Prostko-Prostyński, Utraeque res publicae. The Emperor Anastasius I’s Gothic Policy (491-518), Poznań 1994.

${ }^{19}$ Wyprawy wizygockie pod dowództwem Cyrili, Sunieryka, Wiktoriusza, czy Wincencjusza, ostrogockie Ibby, Tuluina, Ary, Gunduina i Pitzy, zwycięstwo wandalskiej floty w 468 r. pod dowództwem Gentona, czy ekspedycja floty wandalskiej na Sardynię dowodzona przez Tzazona. W przypadku Swebów wiadomo o jednym tylko przypadku wyprawy Hermigara na Betykę (428), jednak nie wiadomo czy miało tu miejsce scedowanie dowództwa przez króla Hermeryka, czy też samodzielna (samowolna?) akcja Hermigara.

${ }^{20}$ Ich istnienie zgodnie zaświadczają Prokopiusz z Cezarei i Wiktor z Wity. Prokopiusz z Cezarei (De bellis III 5, $11 \mathrm{nn}$., ed. Haury, vol. 1, s. 333-334) informuje o podzieleniu ziemi wokół Kartaginy i nadaniu wojownikom $\kappa \lambda \hat{n} \rho 0 \imath$ B $\alpha \nu \delta i ́ \lambda \omega v, z$ terenów których wygnano większość Rzymian a pozostawionych obrócono w niewolników. Z kolei Wiktor z Wity, cytując edykty króla Huneryka wydawane w 482 r. w związku ze zwoływaną przez niego dysputą religijną w Kartaginie, dwukrotnie wspomina o terytoriach zamieszkałych przez Wandalów: Historia persecutionis II 39, ed. Vössing, s. 86: „Non semel, sed saepius constat esse prohibitum, ut in sortibus Wandalorum sacerdote vestri conventus minime celebrarent [...]"; tamże III 4, ed. Vössing, s. 100-102: ,[...] ut in sortibus Wandalorum nullos conventus omousiani sacerdotes adsumerent $[\ldots]$ ”. 
go, dającego się kontrolować, terytorium bazę mobilizacyjną i rekrutacyjną. W razie potrzeby możliwa była szybka koncentracja wojsk królewskich, co przy zniszczeniu systemu obronnego miast rzymskiej Afryki dawało możliwość podejmowania szybkich i skutecznych kroków pacyfikacyjnych w razie niepokojów ze strony ludności podbitej, tym bardziej, że istnieją przesłanki, by sądzić, że obszar sortes Vandalorum połączony był z Trypolitanią wąskim pasem terenów przybrzeżnych, pozostających też pod kontrolą królewskich wojowników $^{21}$, a zatem utrzymana była kontrola militarna nad najważniejszymi z punktu widzenia królestwa obszarami produkcji zboża i traktami komunikacyjnymi. Prokopiusz z Cezarei wyraźnie zaświadcza, że ziemie przyznane nie tylko krewnym i możnym, ale także wszystkim wojownikom Gejzeryk pozostawił wolnymi od jakichkolwiek podatków, podczas gdy tereny pozostawione pod uprawę Rzymianom obciążył kolosalnymi świadczeniami podatkowymi ${ }^{22}$. Wydaje się jasne, że zwolnienie z podatków było związane z obowiązkiem służby wojskowej na wezwanie królewskie wraz ze zdobywaniem (lub produkcją) i utrzymywaniem w dobrym stanie broni, a może i jakiegoś „pocztu” składającego się z ludzi dbających o broń i zaopatrzenie wojownika tak w czasie pokoju, jak i podczas działań poza terenem jego posiadłości.

O możliwościach mobilizacyjnych armii Gejzeryka najlepiej świadczy sprawność i szybkość z jaką wiosną 455 r. postawiono na nogi zarówno jednostki floty, jak i armię królewską, którą flota ta przerzucić miała do Italii. Do zamordowania Walentyniana III (2 VII 419 - 16 III 455; cesarz od 23 X 425) doszło w połowie marca 455 r., a krótko potem doszło do małżeństwa Palladiusza (ok. 420 - 31 V 455), syna uzurpatora Petroniusza Maximusa (ok. 395 - 31 V 455; cesarz od 17 III 455) z córką zamordowanego cesarza, Eudoksja (439 - ok. 472), która jednak wcześniej zaręczona była z Hunerykiem, synem Gejzeryka. To był powód interwencji, jednak wieści o wydarzeniach w Rzymie dotarły do Kartaginy pewnie na przełomie marca i kwietnia. W maju wojska królewskie lądują na ziemi italskiej w pobliżu Rzymu, a w pierwszych dniach czerwca Gejzeryk stoi u bram Wiecznego Miasta, dorównując prędkością manewrów dużych mas wojsk samemu Gajuszowi Juliuszowi Cezarowi (12 VII 100 - 15 III 44 prz. Chr.). Ta imponująca sprawność nie byłaby możliwa przy większym rozproszeniu wojowników królewskich na rozległym terytorium diecezji afrykańskiej ${ }^{23}$.

${ }^{21}$ Por. A. Merrills - R. Miles, The Vandals, Chester 2010, 63-64; H. Castritius, Die Vandalen, Stuttgart 2007, 97-98.

${ }^{22}$ Por. Procopius Caesariensis, De bellis III 5, 14-15, ed. Haury, vol. 1, s. 333.

${ }^{23}$ Por. Castritius, Die Vandalen, s. 105-106. Autor wyraża także przy okazji zdanie, że prócz znacznej armii interwencyjnej król potrzebował też sprawnej i licznej floty, dla przerzucenia wojsk do Italii. Uważa, że stan floty królewskiej w 455 r. pozwalał bez problemu na wykonanie tego trudnego logistycznie zadania. 
Dużymi oddziałami jazdy lub zgrupowaniami floty dowodzili krewni królewscy ${ }^{24}$. Niewiele jednak wiemy o dowodzeniu na niższych szczeblach. Na pewno stosowano podział dziesiętny, jednak zaświadczonych mamy źródłowo jedynie tysięczników, o czym była już mowa. Owi millenarii pełnili funkcje wojskowe i administracyjne, i dowodzili dużymi jednostkami operacyjnymi. Musieli jednak istnieć także dowódcy niższego szczebla, choćby na potrzeby działań floty korsarskiej. Pirackie rajdy na wybrzeża obydwóch części cesarstwa wymagały wyłonienia szybkich oddziałów desantowych, przewożonych przez nieduże zgrupowania okrętów, trudne do przechwycenia, mogące $\mathrm{w}$ razie potrzeby łączyć się w większe flotylle. Na jedną jednostkę mogło zaokrętować się około dwudziestu królewskich wojowników lub piechurów z mauretańskich oddziałów pomocniczych. Trzy do czterech takich okrętów przewoziło więc oddział, którym mógł dowodzić setnik, natomiast jednostkami sześcio- do ośmiokrotnie liczniejszymi dowodzić mogli tysięcznicy. Zasięg operowania wandalskiej floty korsarskiej był imponujący i wytyczany przez relacja źródłowe na obszarze od brzegów hiszpańskiej Galicji po wybrzeża wysp greckich, choć może czasami można przypuszczać, że mamy do czynienia z przesadą i stosowaniem przez autorów źródeł pewnego stereotypu funkcjonującego na zasadzie „każdy pirat to Wandal”25.

${ }^{24} \mathrm{~W}$ bitwie pod Decimum w 533 r. wandalski kontyngent jazdy podzielił się na trzy nierówne co do liczby wojowników ugrupowania. Główny trzon armii, rosnący w siłę wraz z przybywaniem nowych wojowników z odleglejszych stron, sortes Vandalorum, wiódł sam król Gelimer. Straż przednią prowadził brat królewski Ammatas, a flankę armii osłaniał, grożąc równocześnie rzymskiemu skrzydłu, dowodzący najmniejszym oddziałem jazdy liczącym dwa tysiące bratanek królewski Gibamund (Procopius Caesariensis, De bellis III 18, 1 i 12, ed. Haury, vol. 1, s. 388 i 390). W bitwie pod Kartaginą w 468 r. całością floty królewskiej dowodził syn Gejzeryka, Gendzon (tamże III 6, 24, ed. Haury, vol. 1, s. 339). Za panowania Hilderyka nieustanne utarczki z Maurami na przedpolach Gór Atlas prowadził krewny królewski Hoamer, a prowadził chyba skutecznie, skoro zasłużył na miano „Achillesa Wandalów” (tamże III 9, 2, ed. Haury, vol. 1, s. 351 (,[í] ôv $\delta \grave{\eta}$

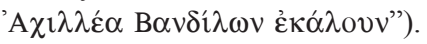

${ }^{25}$ Wyprawy Wandalów na wybrzeża Sycylii i Italii są wielokrotnie potwierdzane przez różne źródła, a operacje flotylli wandalskich korsarzy na brzegach Peloponezu i Zakynthos poświadcza wiarygodna informacja Prokopiusza z Cezarei (De bellis III 22, 15-18, ed. Haury, vol. 1, s. 406407). Mniej wiary można dać spekulacjom na temat atlantyckich wypraw królewskich okrętów. Szczególnie podejrzana jest wiadomość Hydacjusza (Continuatio chronicorum Hieronymianorum 131, MGH Auctores Antiquissimi XI 24), dotycząca 445 r.: „Wandali navibus Turonio in littore Gallaeciae repente advecti, familias capiunt plurimorum”. W jakim celu okręty królewskie podejmowałyby znaczne ryzyko przejścia przez Cieśninę Gibraltarską i żeglugi po otwartym oceanie, by jeszcze w dodatku napadać na ziemie podległe Swebom, których wobec pogorszenia stosunków z Wizygotami Wandalowie postrzegali jako potencjalnych sojuszników. Przecież jest to czas fatalnego pogorszenia stosunków pomiędzy Gejzerykiem a Teodorykiem I, wynikłego z wygnania przez Gejzeryka z Kartaginy jego synowej, księżniczki wizygockiej, córki Teodoryka I, którą król Wandalów oskarżył o próbę otrucia męża i pozbawiwszy nosa i uszu odesłał do ojca. Gejzeryk podejmował na ogół działania przemyślane, a rajd na wybrzeża Galicji nie mieści się w ramach logicznej kalkulacji. Słusznie chyba rozumuje H. Castritius (Die Vandalen, s. 112) stawiając tezę, że 
Jazda wandalska nie dorównywała ciężarem broni defensywnej kawalerii wschodniorzymskiej czy perskiej. Wojownicy przygotowani byli do bezpośredniego starcia z przeciwnikiem, a ich główną bronią były lanca i miecz. Broń miotana i łuk nie były im obce, ale brakowało im doświadczenia w walce na dystans ${ }^{26}$. Jeżeli nie udało się starcia rozstrzygnąć szybką szarżą, wojownicy królewscy z trudem radzili sobie ze stawiającym skuteczny opór przeciwnikiem. Świadczy o tym zmienne powodzenie w walkach z Maurami, którzy oswojeni z walką pieszą potrafili zręcznie wykorzystać naturalne przeszkody i ukształtowanie terenu, by zmusić Wandalów do walki na dystans, a to zazwyczaj kończyło się niepowodzeniem armii królewskiej. Jeszcze silniejszym dowodem jest niepowodzenie podjętej za panowania Thrasamunda wyprawy przeciw Kabaonowi, wodzowi pustynnych koczowników z pogranicza tripolitańskiego. W czasie bitwy Kabaon zastosował taktykę obrony zza kolistej osłony. Ułożone bokiem do atakujących Wandalów wielbłądy Kabaona utworzyły krag obronny o głębokości na 12 zwierząt, zza którego pustynni rabusie odpierali ataki Wandalów tym łatwiej, że odór wielbłądów płoszył konie, a jeźdźcy wandalscy nie potrafili skutecznie prowadzić walki. Wielu z nich zginęło, wielu też dostało się do niewoli ${ }^{27}$.

napastnikami pod Turonium w 445 r. byli sascy piraci. Terror utrzymywany przez Wandalów w całym niemal basenie Morza Śródziemnego był tak przerażający dla Rzymian, że stał się przysłowiowy i we wszystkich okrętach wyłaniających się zza horyzontu i łupiących wybrzeża widziano flotę wandalską, nawet w odległej Galicji, gdzie przecież Sasi, jeżeli to oni łupili, nie przedstawiali się uprzejmie swoim ofiarom, ani nie zostawiali wizytówek na pogorzeliskach. Dla Hydacjusza sprawa była jasna - jak morscy rozbójnicy, to oczywiście Wandalowie. Odrzucając wyprawę oceaniczną jako mało prawdopodobną należy jednak przypomnieć, że Baleary były jak najbardziej pod kontrolą wandalską, co zapewniało kontrolę nad wodami aż po Gibraltar.

${ }^{26}$ Por. Castritius, Die Vandalen, s. $137 \mathrm{nn}$.

${ }^{27}$ Por. Procopius Caesariensis, De bellis III 8, 25-28, ed. Haury, vol. 1, s. 350, thum. D. Brodka: Prokopiusz z Cezarei, Historia wojen, t. 1: Wojny z Persami i Wandalami, Kraków 2013, 231-232. Ciekawe jest, że Kabaon zastosował taktykę zbliżoną do tej, jaką stosowali niegdyś sami Germanie. Formacja znana w historiografii niemieckiej jako „Wagenburg” występuje we wczesnym okresie wędrówki plemion germańskich, o czym przekonany był już Wegecjusz, stawiając nawet barbarzyńców Rzymianom za przykład jako tych, którzy zabezpieczając obozy w czasie nocnego postoju otaczają je kołem wozów, por. Flavius Vegetius Renatus, Epitoma rei militaris, ed. C. Lang, Lipsiae $1885^{2}, 92$ : „Omnes barbari carris suis in orbem conexis ad similtudinem castrorum securas a superuentibus exigunt noctes”. O zastosowaniu „Wagenburga” przez Gotów w operacjach związanych $\mathrm{z}$ bitwą pod Adrianopolem dwukrotnie wspominał Ammianus Marcellinus (Res gestae lib. XXXI 7, 6-7 i XXXI 12, 11, ed. G. Sabbah: Ammien Marcellin, Histoires, t. 6: Livres XXIX-XXXI. Index general, introduction, texte et traduction par G. Sabbah, notes par L. Angliviel de la Beaumelle, Paris 1999, 121-122 i 141). Alaryk w 402 r. po poniesionej z ręki Stilichona klęsce zamknął się w warownym obozie, który zbudowano na jednym ze wzgórz w pobliżu Werony. Uprzednio w czasie samej bitwy tabor nie odegrał żadnej roli, szybko opanowany po zaskakującym ataku Rzymian przeprowadzonym w Niedzielę Wielkanocną. Rzymianie wzięli w taborze Alaryka liczne łupy i jeńców, jednak sam król z większością wojsk uniknął rozbicia i obwarował się we wspomnianym już obozie na wzgórzu. Nie ma jednoznacznego przekazu dowodzącego, że był to „Wagenburg”, ale 
Obok wandalskiej i alańskiej jazdy w armii królestwa wykorzystywano mauretańskie oddziały pomocnicze, zazwyczaj piesze, które najcześciej służyły jako jednostki zwiadu w rajdach korsarskich, zdatne też do łupieżczych wypadów w głąb lądu i do zgarniania i pilnowania jeńców ${ }^{28}$. Obsługa floty z kolei składać się musiała z przedstawicieli ludności prowincjonalno-rzymskiej, ponieważ sami Wandalowie nie posiadali, przynajmniej początkowo, wykwalifikowanej kadry. Być może z biegiem czasu dowódcy wandalscy nabrali nieco marynistycznego doświadczenia, jednak brak na to dowodów źródłowych, a nawet jeżeli przypuszczenie to jest słuszne, to zapewne dowodzili oni okrętami i flotyllami, natomiast obsługa okrętów - marynarze i wioślarze - na pewno nie była wandalska. Flota ta, poza głównym miejscem stacjonowania w wojennym porcie kartagińskim, dysponowała punktami oparcia na Balearach, Sardynii, Korsyce i w zachodniej Sycylii. Umożliwiało to w razie potrzeby znalezienie bezpiecznego schronienia oraz zaopatrywania floty. Dodatkowo Sardynia była miejscem pozyskiwania drewna na potrzeby floty i prawdopodobnie także napraw i budowy okrętów wojennych. Na koniec omówienia armii wandalskiej warto wspomnieć jeszcze o prawdopodobnie istniejących jednostkach jazdy odpowiadających cesarskiej gwardii. Trudno sobie wyobrazić by władcy poruszali się bez odpowiedniej eskorty zapewniającej bezpieczeństwo. Przypuszczenie to potwierdza, choć nie bezpośrednio, wzmianka Wiktora z Wity o godnym pożałowania losie przedstawicieli kartagińskiego kleru, którzy korzystając z przejażdżki Gejzeryka nad brzegiem

szybkie zaimprowizowanie umocnień tuż po przegranym starciu było możliwe jedynie przy częściowym choćby wykorzystaniu wozów. Omówienie tych wydarzeń i wykaz związanych z nimi źródeł został umieszczony w przypisach rozprawy: M. Wilczyński, Germanie w stużbie zachodniorzymskiej w V w. n.e. Studium historyczno-prosopograficzne, Kraków 2001, 137nn. Dyskusję na temat lokalizacji i zadań warownego obozu Alaryka prowadzili Herwig Wolfram (Die Goten, s. 159), Andreas Schwarcz (Reichsangehörige Personen gotischer Herkunft. Prosopographische Studien, Wien 1984 (maszynopis), 183) i Siegmar Döpp (Zeitgeschichte in Dichtungen Claudians, Hermes Einzehlnschriften 43, Wiesbaden 1980, 207). Obóz-tabor nie jest, co ciekawe, stosowany przez dowódców germańskich w wojnach toczonych przez królestwa Wandalów, Gotów czy Burgundów. W ostatniej bitwie królestwa Wandalów, stoczonej w 534 r. pod Tricamarum, pojawia się wprawdzie obóz warowny, zdobyty przez wojska Belizariusza (ok. 505-565), ale z relacji Prokopiusza z Cezarei wynika, że był to zwyczajny obóz umocniony palisadą, stanowiący schronienie dla rodzin i mienia wojowników.

${ }^{28} \mathrm{~W}$ panegiryku ku czci cesarza Majoriana (ok. 420 - 7 VIII 461; cesarz od 1 IV 457 do 2 VIII 461) Sydoniusz Apolinary wymienia nawet z nazwy plemiona dostarczające Wandalom jednostek posiłkowych, por. Sidonius Apollinaris, Carmina V 335-337, MGH Auctores Antiquissimi VIII 196: „propriis nil conficit armis: Gaetulis, Nomadis, Garamantibus, Autololisque, Arzuge, Marmarida, Psyllo, Nasamone timetur sequis". Nieco dalej (tamże V 390-392 i 400-402, MGH Auctores Antiquissimi VIII 197) szydzi z tłustego Wandala, który sam tchórzliwie siedzi na okrętowej ławie, a swoim sługom (Maurom) każe zapędzać na okręty jeńców i znosić łupy, jak też z uzbrojenia oddziałów napadających wybrzeża rzymskie, wśród którego wymienia łuki i strzały nasycone trucizną, co jest ewidentnie elementem uzbrojenia mauretańskich oddziałów posiłkowych. 
morza próbowali zyskać posłuch królewski dla swoich próśb o ograniczenie prześladowań. Gejzeryk początkowo polecił ich potopić w morzu, jednak uproszony przez ,swoich" zamiaru tego nie przeprowadzi1 ${ }^{29}$. Niewatpliwie „swoi” otaczający Gejzeryka to wandalscy dworzanie i słudzy dworu królewskiego, obdarzeni wyczuciem politycznym na tyle, że topienie kleru wprost na wybrzeżu kartagińskim uznali za zbyt ryzykowne, wątpliwe więc, by to im król polecił topić petentów. Nie zamierzał też zapewne czynić tego osobiście, zatem wykonawcami popędliwego rozkazu musieli być wojownicy wandalscy, stanowiący konną eskortę władcy w czasie przejażdżki i zapewne także w innych okolicznościach.

Armia królestwa Wizygotów miała początkowo zapewne podobną strukturę organizacyjną, jak wandalska. Dużymi zgrupowaniami wojsk dowodził król, krewni królewscy ${ }^{30}$ lub duksowie. Co ciekawe już w okresie istnienia państwa tuluzańskiego na wysokich szczeblach dowodzenia pojawiają się Rzymianie, co jest zjawiskiem zasadniczo różniącym wojskowość wizygocką od wandalskiej. Niżej w hierarchii wojskowej stoją tysięcznicy. Jako odpowiednik wandalskiego millenariusa występuje u Wizygotów piufaps (thiufa$d u s)^{31}$. Niestety znany jest tylko w nielicznych wzmianek źródłowych i nie sposób stwierdzić tak dokładnie, jak w przypadku Wandalów, czy dowódca ten pełnił obok funkcji wojskowych także cywilne. Należy przypuszczać że tak, ponieważ oprócz zachowania administracji municypialnej Wizygoci daleko mniej niż ich pobratymcy pod panowaniem Teodoryka Wielkiego przestrzegali zasady oddzielenia administracji cywilnej (rzymskiej) od wojskowej (gockiej). Chętnie też stosowano na dworze wizygockim rzymskie nazwy urzędów wojskowych takich jak comes spathiatorum, stabuli, largitionum, przy czym tytuły te mogły ozdabiać tak Gotów jak i Rzymian ${ }^{32}$. Można przypuszczać, że w okresie królestwa tuluzańskiego armię obok exercitus Gothorum (czyli trzonu plemiennego) uzupełniali skonfederowani z Wizygotami barbarzyńcy oraz stacjonujące na terenie Galii dawne jednostki laeti i gentiles. Już za panowania Teodoryka I do działań armii królewskiej w obronie kraju przyłączały się prywatne jednostki bucellarii, utrzymywane przez rzymską arystokrację galijską. W czasach toledańskiego państwa Wizygotów, szczególnie po panowaniu

${ }^{29}$ Por. Victor Vitensis, Historia persecutionis, ed. Vössing, s. 42.

${ }^{30}$ W czasie kampanii 408-410 w Italii obok sił głównych Alaryka operował na północy parotysięczny korpus dowodzony przez Ataulfa, szwagra królewskiego, por. Wilczyński, Germanie, s. $168 \mathrm{nn}$. Znane są też samodzielne operacje wojskowe prowadzone za panowania Teodoryka II przeciwko bagaudom lub Frankom, którymi dowodził brat króla, Fryderyk, por. tamże, s. $212 \mathrm{nn}$.

${ }^{31}$ Źródła jak w nocie 17. Por. też Wolfram, Die Goten, s. 222-223.

32 Por. tamże, s. 223-224. Na marginesie warto wspomnieć, że autor wskazuje na ciekawy wyjątek wśród zromanizowanych nazw urzędów. Otóż podczaszy zachował swoją plemienną nazwę. Z właściwym sobie poczuciem humoru H. Wolfram sugeruje, że skoro istniało rzymskie przysłowie „pijąjak Goci”, to znalezienie w mowie Rzymian stosownej nazwy dla tak ważnego urzędu było po prostu niemożliwe. 
Leowigilda († 586) i Rekkareda (ok. 560-601; król od 586), niska aktywność bojowa armii królestwa powoduje osłabienie jej walorów militarnych. Walki przeciw Frankom najeżdżającym czasem królestwo z Akwitanii, jednak bez dążenia do aneksji królestwa, czy z baskijskimi rabusiami, którzy byli co prawda uciążliwi, ale nie stanowili poważnego zagrożenia dla państwa, nie zastapiły występującej w VI w. mobilizacji sił wobec poważniejszych przeciwników takich jak królestwo Swebów w Galicji i Luzytanii, czy enklawa bizantyjska na południu półwyspu. Smutnym przykładem niskiej wartości bojowej armii Wizygotów po VI w. jest stosunkowo łatwy sukces nielicznych wojsk arabskich Tarika (ok. 670-720), którym uległ dysponujący (przynajmniej teoretycznie) dużo większymi siłami król Roderyk († 711; król od 710). Wraz ze stabilizacją państwa w Hiszpanii armia zmienia się z plemiennej, wspieranej siłami Rzymian, w feudalną armię rekrutowaną ze wszystkich warstw społeczeństwa hiszpańskiego. Możni świecy i duchowni, tak pochodzenia rzymskiego jak i gockiego, zobowiązani byli do troski o poziom gotowości bojowej swoich oddziałów, jednak dokumenty prawne, np. z okresu panowania króla Wamby dowodzą, że z powinności tych nie wywiązywali się skwapliwie ${ }^{33}$. Podobnie jak w przypadku Wandalów można przypuszczać, że i u Wizygotów funkcjonowało coś na kształt gwardii królewskiej, zapewne jako kontynuacja dawnej drużyny wodza ${ }^{34}$. Niewiele można powiedzieć o flocie wizygockiej. Źródłowo poświadczone są jedynie jej niepowodzenia (próby przepraw do Afryki podejmowane przez Alaryka i Walię) ${ }^{35}$. Nigdy nie osiagnnęła ona większego znaczenia, ani nie zwróciła na siebie uwagi dziejopisów.

${ }^{33}$ Por. Leges Visigothorum IX 2, 8, ed. Zeumer, s. 370-373. Wydany 1 listopada 673 r. edykt Wamby wprowadza srogie kary w stosunku do feudałów opieszale spełniających swoje powinności militarne wobec monarchy. Znamienne wydaje się ciągłe zagrożenie brakiem dyscypliny, mimo kar pieniężnych i cielesnych (por. nota 17), a skłonność do dezercji cechuje poddanych toledańskiego królestwa Wizygotów niezależnie od zajmowane w armii stanowiska. O prywatnych oddziałach w królestwie Wizygotów, por. Maier, Amtsträger, s. 181nn.

${ }^{34}$ Sydoniusz Apolinary (Epistulae I 2, 4 i 10, MGH Auctores Antiquissimi VIII 3 i 4), opisując dzień życia Teodoryka II, kilkakrotnie wspomina o wojownikach stanowiących bezpośrednią straż króla. Już przy porannej modlitwie i rozmowach z ariańskimi duchownymi Teodorykowi II towarzyszy niewielki oddział straży. W czasie przedobiednich audiencji bezpośrednio przy królu stoi jedynie giermek, jednak ,tłum żołnierzy w skórach” dyskretnie skrywa się za zasłonami, zachowując ciszę, by nie przeszkadzać w posłuchaniach, ale też gotów do nagłej interwencji, a wieczorem wojownicy zajmują wyznaczone pozycje, by czuwać nad snem królewskim. Znane są też przypadki zemsty drużynników lub na drużynnikach króla. Jedna z wersji relacji o morderstwie dokonanym na królu Ataulfie winą obarcza Dubiusa, drużynnika innego gockiego wodza, który spełnił obowiązek i pomścił śmierć swojego pana, zabitego niegdyś z rozkazu Ataulfa. Rzezie na dworze w Barcelonie w 415 r., następujące kolejno po przejęciu władzy przez Sigeryka i Walię, obejmowały nie tylko zwolenników, ale także drużynników zamordowanych królów. Por. Wilczyński, Germanie, s. 178, 198 i 457.

${ }^{35} \mathrm{O}$ nieudanych wyprawach morskich Wizygotów, por. Paulus Orosius, Historiae adversum paganos VII 43, 11-12, ed. Arnaud - Lindet, t. 3, s. 129-130; Olympiodorus, Fragmenta 15, ed. 
Armia ostrogockiego królestwa w Italii, choć pod względem podziału na jednostki dziesiętne zapewne nie odbiegała od pozostałych armii plemiennych, jednak pod wieloma względami różniła się od wizygockiej. Jeżeli chodzi o bazę rekrutacyjną bliżej jej do wzorca wandalskiego, co wynika z wyraźnego i przestrzeganego w królestwie Teodoryka Wielkiego podziału na sferę cywilną i militarną działalności państwa. Absolutny monopol militarny mają w Italii Ostrogoci, choć czasem w źródłach można znaleźć dowódców o imionach rzymskich takich jak Liberius, Cyprianus czy Servatus. Monopol ten zostanie dopiero naruszony w okresie schyłkowym istnienia królestwa, w niespokojnych czasach wojny z Bizantyńczykami, kiedy król Totila († 552; król od 541) nie będzie bronił wstępowania pod gockie znaki bojowe mieszkańcom Italii; była to jednak sytuacja doraźna i trwająca zbyt krótko, by wytworzyć stałe mechanizmy poboru i współdziałania. Należy pamiętać, że od strony formalno-prawnej aż do śmierci Amalasunty (ok. 495-535) ostrogocka armia Italii była armią rzymska, a król występował zarówno jako władca plemienia (tak w aspekcie cywilnym jak i wojskowym), jak i jako najwyższy dowódca i urzędnik cesarski w Italii jako magister militum i patricius. Pozorna obfitość źródeł dotyczących organizacji państwa i armii, którą cieszyć się możemy dzięki Aureliuszowi Kasjodorowi (ok. 485 - ok. 580) wcale nie ułatwia prób rekonstrukcji struktury organizacyjnej armii ostrogockiej Italii. Nie ma wątpliwości, co do dowódców najwyższego szczebla. Królewscy duces zajmujący również miejsce w najwyższych warstwach arystokracji plemiennej dowodzili w ramach dużych samodzielnych operacji przeciw Frankom, Gepidom jak też w strefie naddunajskiej. Ibba i Tuluin pełnili nawet funkcję królewskich rządców, kierujących sprawami gockiej Hiszpanii w okresie istnienia ostrogocko-wizygockiej unii personalnej po śmierci Alaryka II. Na niższych szczeblach dowodzenia pojawiają się comites różnego rodzaju i różnego zakresu kompetencji (wojskowi, miast, rejonów), którzy obok funkcji czysto militarnych spełniają też zadania administracyjne, sądownicze i ekonomiczne, także częściowo wobec ludności rzymskiej, szczególnie w przypadkach interakcji pomiędzy Ostrogotami a Rzymianami, choć przypadki takie wspominane są dość rzadko ${ }^{36}$. W ostrogockiej hierarchii wojskowej pojawiają się także „saiones". Sajoni militarni nie są wojskowymi o stałym zakresie obowiązków, a raczej powoływanymi do specjalnych zadań zaufanymi dowódcami królewskimi. Zlecane im zadania zaliczyć można do zakresu działań stricte dowód-

Blockley, vol. 2, s. 176; Iordanes, Getica 157, ed. Th. Mommsen, MGH Auctores Antiquissimi V/1, Berolini 1882, 99. W obydwóch przypadkach trudno mówić o flocie wojennej. Była to raczej zbieranina skonfiskowanych statków rzymskich i skleconych ad hoc jednostek pływających, przypominjących bardziej tratwy niż wojenne okręty. Nie można oczywiście założyć, że były one obsługiwane przez Gotów. Przynajmniej statki musiały mieć rzymską załogę, jednak zarówno stan floty, jak i nieznajomość zasad bezpiecznej żeglugi spowodowały, że flotą wizygocką pokonało samo morze, zanim doszło do starcia z nieprzyjacielem.

${ }^{36}$ Por. Maier, Amtsträger, s. 210nn. 
czych, ale także mobilizacyjnych i aprowizacyjnych ${ }^{37}$. Wobec zagrożenia ze strony floty wandalskiej i bizantyńskiej Teodoryk Wielki podjął starania o rozbudowę własnych sił morskich, tak przynajmniej wynika z listu skierowanego przez króla, a kwieciście zredagowanego przez Kasjodora, do odpowiedzialnego za budowę floty senatora Abudancjusza, w którym władca wychwala zasługi adresata i, co znamienne, z satysfakcją stwierdza, że „non habet quod nobis Graecus imputet aut Afer insultet", czyli że nie góruje już nad Ostrogotami ani Afrykańczyk (Wandalowie) ani Grek (Bizancjum) ${ }^{38}$. Górnolotne słowa wyraźnie wskazują na cel militarny rozbudowy floty Teodoryka Wielkiego, który obawiał się zagrożenia brzegów Italii i Sycylii ze strony znacznie silniejszych od ostrogockiej flot wandalskiej i cesarskiej. W innym z kolei liście, kierowanym do Benenata, Teodoryk troszczy się o uzupełnienie obsad wioślarzy na okrętach wojennych i zaleca uzupełnienie strat spowodowanych śmiercią części wioślarzy ${ }^{39}$. Mimo wszystko piękne frazy Kasjodorowego tekstu nie przysłaniają rzeczywistego stanu rzeczy - flota ostrogocka nie odgrywała znaczącej roli w basenie Morza Śródziemnego i jeżeli stanowiła jaką́s przeciwwagę dla floty wandalskiej i cesarskiej, to jedynie w zakresie patrolowania i ochrony brzegów Italii. Jak większość flot starożytnych spełniała głównie funkcje transportowe, co Kasjodor pięknie podkreśla, nazywając ją nogami (butami) armii, które nigdy nie ustają ze zmęczenia ${ }^{40}$.

O wojsku królestwa Swebów wiemy bardzo mało. Początkowo na pewno jest to wojsko czysto plemienne. Okres swebskich depraedationes na terenie Galicji nie sprzyjał integracji z miejscową ludnością, a rzymscy possesores nie tylko nie przyłączają się, jak u Wizygotów, do struktur militarnych królestwa, ale przez dłuższy czas je skutecznie zwalczają, prowadząc działania obronne i zaczepne na czele swoich prywatnych oddziałów i być może skleconych ad hoc jednostek lokalnej samoobrony ${ }^{41}$. Ten stan, mimo oficjalnie zawartych

${ }^{37}$ Jako przykład służyć może krótki list, w którym Teodoryk Wielki zwraca się do sajona Wiligisa z poleceniem dostarczenia w okolice Pawii drogą wodną zapasów zboża umożliwiających utrzymanie dworu i podążającego za nim tłumu petentów, por. Aurelius Cassiodorus, Variae, II 20, MGH Auctores Antiquissimi XII 57.

${ }^{38}$ Por. tamże V 17, 3, MGH Auctores Antiquissimi XII 153: „Ornasti rem publicam tua institutione reparatam. non habet quod nobis Graecus imputet aut Afer insultet”.

${ }^{39}$ Por. tamże IV 15, MGH Auctores Antiquissimi XII 121. Przy okazji można uzmysłowić sobie jak dalece jeszcze model dowodzenia tkwił w tradycji plemiennej. Król, mimo rozbudowanej hierarchii wojskowej, poświęca swą uwagę sprawie, której bieżącym rozwiązaniem powinien zajmować się dowódca flotylli, a nawet pojedynczego okrętu.

${ }^{40}$ Por. tamże V 17, 2, MGH Auctores Antiquissimi XII 153: „[...] obtulisti oculis nostris subito classeam silvam, domos aquatiles, exercituales pedes, qui nullo labore deficient [...]".

${ }^{41}$ Był to opór skuteczny i źle świadczący o możliwościach bojowych wojowników królewskich, ustępujących lokalnym oddziałom samoobrony. Ostatecznie doszło do rokowań i kompromisowych ustaleń pokojowych o czym informował Hydacjusz (Continuatio chronicorum Hieronymianorum 91. 96 i 113, MGH Auctores Antiquissimi XI 21-23). 
traktatów pokojowych i pojednawczych kroków ${ }^{42}$, uległ konserwacji w czasach rozbitego królestwa po śmierci króla Rechiara w 456 r. (panował od 448) aż do momentu jedynowładztwa Rechimunda († ok. 463; król od 460), kiedy to powróciły dawne swebskie grabieże, a ludność rzymską traktowano niemal wyłącznie jako obiekt rabunku. Wydaje się, że aż do schyłku panowania Rechimunda armia swebska nie wyszła poza fazę organizacji armii plemiennej, skupionej wokół swojego wodza, a w sytuacjach krytycznych wodza tego obierającej lub obalającej, o czym najlepiej świadczy historia wyboru i zamordowania króla Maldrasa († 460; król od 456/457) ${ }^{43}$. Znany problem prawie osiemdziesięcioletniej luki w materiale źródłowym nie ułatwia badań. Gdy królestwo wyłania się z kronikarskiego niebytu w okresie 550-585 r. nadal brak źródłowych informacji o strukturze państwa i armii. Oczywiście głównodowodzącym jest król [Miron w 583 r., czyli w roku swej śmierci, osobiście prowadzi posiłki na pomoc walczącemu z ojcem wizygockiemu królewiczowi Hermenegildowi (ok. 560-585)] ${ }^{44}$, jednak nie znamy niższych szczebli dowodzenia. W aktach synodu luceńskiego (569 r.), których prawdziwość budzi jednak poważne zastrzeżenia, wymienieni są królewscy comites, zarządzający regionami, w liczbie 10 lub 11, wśród nich dwóch noszących zdecydowanie rzymskie imiona ${ }^{45}$. Zapewne pełnili oni także konkretne funkcje militarne, jednak nie dysponujemy żadnymi wiadomościami na ten temat. Podobnie nic nie wiadomo o flocie Swebów. Ze wzmianki, że po przegranej bitwie pod Paramo w 456 r. król Rechiar usiłował daremnie przedostać się do Portumcale (Porto), by tam skorzystać z możliwości ewakuacji drogą morską ${ }^{46}$, można ewentualnie wysnuć przypuszczenie, że stały tam jakieś statki (okręty?) podlegające rozkazom króla, ale nie można nic wnioskować o istnieniu lub organizacji regularnych sił morskich.

${ }^{42} \mathrm{Na}$ pewno zawierane kolejno porozumienia z mieszkańcami Galicji stanowią przykłady prób pojednania z ludnością rzymską jednak największą szansą na zbliżenie obydwóch społeczności stanowił przyjęty w 448 r. katolicki chrzest Rechiara, jednak dalsza polityka króla, a szczególnie jego krótkie ośmioletnie panowanie, nie dała możliwości umocnienia tendencji koncyliacyjnych (jeżeli istniały). Później w okresie królestwa podzielonego władcy Swebów wracają do praktyki rabowania podległych sobie terenów, co na długi czas odbudowało mur niechęci między ludnością prowincjonalną a barbarzyńcami. Por. M. Wilczyński, Królestwo Swebów - regnum in extremitate mundi, Kraków 2011, 133nn.

${ }^{43}$ Por. Hydatius Lemicus, Continuatio chronicorum Hieronymianorum 181. 188 i 198, MGH Auctores Antiquissimi XI 29-31.

${ }_{44}$ Jednoznacznie zaświadczają o tym Jan z Biclaro (Iohannes Biclarensis, Chronikon 225, ed. J. Campo: Juan de Biclaro, Su vida y su obra, introducción, texto crítico y comentarios por J. Campo, Escuela de Estudios Medievales. Estudios 32, Madrid 1960, 91) i Grzegorz z Tours (Gregorius Turonensis, Historia Francorum VI 43, ed. B. Krusch - W. Levison, MGH Scriptores Rerum Merovingicarum I/1, Hannoverae 1951, 314-315.

${ }^{45}$ Por. Divisio Teudemiri, ed. Costa, s. 23.

${ }^{46}$ Por. Hydatius Lemicus, Continuatio chronicorum Hieronymianorum 175, MGH Auctores Antiquissimi XI 29. 
Stosunek kawalerii do piechoty nie był identyczny w omawianych królestwach. Oczywiście w wandalskiej Afryce jazda ma absolutną przewage W strukturze broni. W obydwóch państwach gockich znane są silne kontyngenty kawalerii, a opis wojny gockiej autorstwa Prokopiusza z Cezarei wskazuje jednoznacznie na kluczową rolę jazdy w armii Ostrogotów. Podobnie było u Wizygotów, którym posiadane oddziały jazdy zapewniały przewagę prędkości przemieszczania się i siły uderzenia nad wojskami Swebów, które - jak można wnioskować z krótkiej wzmianki Jordanesa († po 552) o sposobach walki różnych ludów barbarzyńskich - były zapewne przynajmniej w części piesze ${ }^{47}$.

O ile każdy wojownik w okresie plemiennym zapewniał sobie aprowizację i uzbrojenie, to w królestwach barbarzyńskich nawet we wczesnej fazie ich istnienia widać nową dążność do zapewniania armii większych, zewnętrznych dostaw zboża, a w konsekwencji do zdobycia terytorium, na którym można przez nadania ziemi zapewnić wojownikom odpowiednie uposażenie. Także zaopatrzenie w broń i sprzęt wojenny, początkowo stanowiące przedmiot indywidualnej troski wojownika, zmienia się w konfrontacji z zastaną na terenie imperium organizacją administracji wojskowej. Pierwszymi sygnałami zwiastującymi to zjawisko jest dążenie wodzów plemiennych do uzyskania statusu magister militum, co poza podniesieniem ich prestiżu w oczach ludu, mogło dawać jeszcze możliwość skorzystania z logistycznych prerogatyw tego urzędu wojskowego. Wśród prerogatyw tych ważny był nadzór sprawowany nad fabricae, czyli państwowymi wytwórniami sprzętu wojskowego na danym terytorium ${ }^{48}$. W okresie późniejszym zaświadczone są źródłowo królewskie

${ }^{47}$ Por. Iordanes, Getica 261, MGH Auctores Antiquissimi V/1 125: „Nam ibi admirandum reor fuisse spectaculum, ubi cernere erat contis pugnantem Gothum, ense furentem Gepida, in vulnere suo Rugum tela frangentem, Suavum pede, Hunnum sagitta praesumere" - przy opisie bitwy nad Nedao znajdujemy charakterystykę sposobu walki różnych ludów. Tę dość kruchą podstawę rozumowania można jeszcze wzmocnić, przypominając o niezwykłej skuteczności wojsk Cyrili i Sunieryka w zwalczaniu i ściganiu swebskich oddziałów, w okresie rozbicia królestwa jak też o łatwym zwycięstwie odniesionym pod Paramo przez w większości konną armię Teodoryka II. Por. Wilczyński, Królestwo Swebów, s. 158nn.

${ }^{48}$ Klaudiusz Klaudian miał być może właśnie to na myśli, gdy w usta Alaryka włożył wypowiedź: „At nunc Illyrici postquam mihi tradita iura / Meque suum facere ducem; tota tela tot enses / Tot galeas multo Thracum sudore parawi / Oppida legitimo iussu Romana coëgi" (Claudius Claudianus, De bello Polentino sive Gothico 535-539, w: tenże, Carmina, ed. Th. Birt, MGH Auctores Antiquissimi X, Berolini 1982, 279. Jeżeli przyjmiemy choć w części prawdziwość tej chełpliwej wypowiedzi, to mamy do czynienia z zagarnięciem produkowanej w położonych na północy Bałkanów warsztatach podległych najwyższej władzy wojskowej broni. Jak wiadomo istnieją przypuszczenia, że Alaryk wtargnął na Bałkany po otrzymaniu stopnia magister militum (per Thraciam?) od Rufina w czasie rokowań pod murami Konstantynopola, por. Wilczyński, Germanie, s. 128nn. Magistrami militum byli poza Alarykiem, Athaulf, Fryderyk, brat Teodoryka II, a może nawet sam Teodoryk II, także królowie Burgundów, Gundiok i Gundobad, jak też u Ostrogotów Teodoryk Wielki. Ciekawe jest jednak, że w strukturze żadnego z omawianych królestw nie pojawia się własny magister militum. 
magazyny broni w Kartaginie, organizowane już w zakresie własnych przedsięwzięć administracyjnych Wandalów ${ }^{49}$. Produkcja broni mogła poza tym pozostawać w zakresie kompetencji niższych dowódców. Znamy przypadek wandalskiego millenariusa, który zatrudniał rzymskiego zbrojmistrza w swoich włościach ${ }^{50}$.

Armie barbarzyńskich królestw mobilizowano, przynajmniej w obrębie armii plemiennej, jako pospolite ruszenie, co nie wykluczało utrzymywania niewielkich ilości wojska w służbie stałej jako przyboczne oddziały królewskie, garnizony miejskie czy portowe, bądź obsada ważnych strategicznie punktów (np. garnizon na ważnej strategicznie dla wandalskiej floty Sardynii ${ }^{51}$ ).

$* * *$

Jak widać wojskowość germańskich królestw na dawnym terytorium cesarstwa w basenie Morza Śródziemnego rozwijała się różnorodnie, w zależności od statusu i strategicznych celów władców. Wykazane w powyższym artykule podobieństwa i różnice nie wyczerpują na pewno tematu, który wymaga dalszych, poważnych badań. Pewną nadzieję wiązać można z potencjalnymi znaleziskami archeologicznymi oraz reinterpretacją materiału archeologicznego i źródłowego. W przeciwieństwie do bardzo daleko idących porównań modeli powstających $\mathrm{w}$ nieporównywalnych wzajemnie okolicznościach ta droga wydaje się jedyną możliwą. Na pewno armie królestw Wandalów, Gotów i Swebów wykazują znaczny wpływ warunków, w których działały, na ich organizację, szczególnie administracji i sztuki zarządzania Rzymian, w znacznej części przecież wykorzystywanej przez germańskich monarchów. Trudo było utrzymać społeczność rzymską i barbarzyńską w całkowitej izolacji. Dochodziło do wielu kompromisów i rozwiązań, skutkiem których w szeregach królewskich wojsk pojawiają się i Rzymianie na różnych szczeblach, co prowadziło do powstania swoistego konglomeratu odmiennego od struktur krzepnących w tym okresie w północnym Barbaricum.

\footnotetext{
Wprawdzie Odoaker (ok. 433-493) nadał tę rangę swojemu synowi Theli oraz wodzowi Tufie, jednak stało się to w czasie wojny z Teodorykiem Wielkim, w sytuacji nadzwyczajnej i było chyba próbą podkreślenia legalności władzy wojskowej sprawowanej w imieniu cesarza.

${ }^{49}$ Por. Prokopius Caesariensis, De bellis III 7, 9-10, ed. Haury, vol. 1, s. 341. Prokopiusz opowiada, jak cesarz Majorian w przebraniu, udając własnego posła, dotarł do Kartaginy, gdzie Gejzeryk, chcąc na wysłanniku cesarskim wywrzeć wrażenie, zaprezentował mu budynek, w którym zgromadzono wielką ilość doborowej broni.

${ }^{50}$ Por. Victor Vitensis, Historia persecutionis, ed. Vössing, s. 50.

${ }^{51}$ Sardynią stale zarządzał w imieniu króla namiestnik. Znany jest Got imieniem Godas, który będąc wandalskim namiestnikiem Sardynii za namową dyplomacji Justyniana I Wielkiego (ok. 483 - 14 XI 565; cesarz od 1 VIII 527) podniósł bunt przeciw królowi Wandalów Gelimerowi, por. Prokopius Caesariensis, De bellis III 10, 25-31, ed. Haury, vol. 1, s. 359-360.
} 


\title{
EXERCITUS BARBARORUM. \\ THE ORGANISATION AND THE WARFARE OF THE ARMIES OF \\ GERMANIC PEOPLE IN THE V-VI CENTRURIES \\ IN THE MEDITERRANEAN AREA
}

\begin{abstract}
(Summary)
Organization of the armies of the barbarian states that emerged on the coasts of the Mediterranean Sea in the $5^{\text {th }}$ and $6^{\text {th }}$ centuries can only partially be reconstructed. Primary sources and archeological records vary depending on the state. The preserved evidence relating to the military power of the Vandals and Goths is relatively good, much less is known about the Svevs. All of the discussed barbarian armies were presumably grouped into units based on ten. Better insight can only be provided into the top military ranks. An interesting issue presented in the thesis is to what degree the former tribal structures were preserved and how far the Roman models were followed by the barbaric people. None of the armies of the kingdoms referred to above can fully be compared with the Germanic army that existed in the north of the Medieval Europe, which inevitably leads to substantive errors. All the foregoing kingdoms had armies mostly composed of native warriors which, however, did not guarantee their purely Germanic character. The author tries to determine to what extent the Roman population or inhabitants of certain provinces, e.g. the Moors joined the military organizations of kingdoms under the Germanic rule. Examples of the Roman officers and commanders who sought carrier in the Gothic army or representatives of subdued nations serving in the Vandals' navy or auxiliaries encourage to perform further study in this field.
\end{abstract} Svevs.

Key words: Late Antiquity, Armies of Germanic People, Vandals, Goths,

Słowa kluczowe: późny antyk, armie ludów germańskich, Wandalowie, Goci, Swebowie. 
